\title{
PELAKSANAAN PUTUSAN PENGADILAN TATA USAHA NEGARA
}

\author{
TESSYA PUTRI PERMATA SARI \\ tessyaputri89@gmail.com \\ 1910003600569 \\ UNIVERSITAS EKASAKTI PADANG
}

\section{A. PENDAHULUAN}

Indonesia merupakan negara yang berlandaskan atas hukum yang ditegaskan dalam Undang-Undang Dasar Negara Republik Indonesia 1945 Pasal 1 ayat (3). Oleh sebab itu segala kesewenangan dan tindakan alat-alat perlengkapan negara atau penguasa, semata-mata berdasarkan hukum atau dengan kata lain diatur oleh hukum. Sistem ketatanegaraan Indonesia dikenal dengan trias politika maksudnya ada 3 (tiga) cabang kekuasaan yaitu Eksekutif, Legislatif, dan Yudikatif. Eksekutif memiliki porsi peran dan wewenang yang paling besar apabila dibandingkan dengan yang lain. Kekuasaan pemerintah tidak dapat lepas dari perkembangan asas legalitas yang telah dimulai sejak konsep negara hukum klasik formele rechtstaat atau liberale rechtsstaat yaitu wetmatigheid van bestuur artinya pemerintahan menurut undang-undang. Setiap tindakan pemerintah harus berdasarkan kepada undang-undang.

Konsekuensi dari sebuah negara hukum adalah wajib adanya jaminan bagi administrasi negara sebagai alat perlengkapan negara untuk dapat menjalankan pemerintahan dan warga negara memiliki hak dan kewajiban mendapat jaminan perlindungan. Untuk mengontrol kekuasaan eksekutif tersebut diperlukan lembaga yudikatif atau kehakiman. Salah satu bentuk kontrol yudisial atas tindakan administrasi pemerintah adalah melalui lembaga peradilan. Adanya suatu peradilan khusus yang dapat menyelesaikan jika terjadi sengketa antara pemerintah dengan rakyat serta memberikan perlindungan hukum bagi rakyat atas tindak 
pemerintahan. Peradilan ini dalam radisi rechtstaat disebut dengan peradilan administrasi atau Peradilan Tata Usaha Negara.

Peradilan Tata Usaha Negara keberadaaannya diamanahkan melalui Undang-Undang Nomor 5 Tahun 1986. Seiring dengan kemajuan zaman dan adanya tuntutan reformasi dibidang hukum maka disahkan Undang-Undang Nomor 9 Tahun 2004 tentang perubahan atas UndangUndang Nomor 5 Tahun 1986 dan Undang-Undang Nomor 51 Tahun 2009 tentang perubahan kedua atas Undang-Undang Nomor 5 Tahun 1986. Pada dasarnya eksistensi Peradilan Tata Usaha Negara sebagai wujud dari pelaksanaan fungsi yudikatif untuk mengontrol jalannya fungsi eksekutif dalam bentuk menguji suatu bentuk keputusan Tata Usaha Negara yang dikeluarkan Pejabat Tata Usaha Negara bahwa keputusan tersebut telah sesuai dengan ketentuan peraturan perundang-undangan dan asas-asas umum penyelenggaraan pemerintah yang layak sesuai dengan pasal 115 Undang-Undang Nomor 5 Tahun 1986 tentang Peradilan Tata Usaha Negara yang menyebutkan bahwa hanya keputusan yang telah memperoleh kekuatan hukum tetap yang dapat dilaksanakan.

Pelaksanaan putusan merupakan bentuk sebagai eksekusi. Eksekusi dapat dilaksanakan jika sudah ada suatu putusan yang memperoleh kekuatan hukum tetap atau pasti. Keberhasilan pelaksanaan (eksekusi) putusan Peradilan Tata Usaha Negara merupakan indikator utama untuk menegakan tegaknya kewibawaan pengadilan dan berhasilnya upaya pencari keadilan. Secara normatif ketentuan tentang pelaksanaan putusan Peradilan Tata Usaha Negara di atur pada pasal 115 dan 116 UU No. 5 Tahun 1986, yang sudah mengalami perubahan dengan dikeluarkannya UU No. 9 tahun 2004 dan UU No. 51 Tahun 2009. 


\section{B. PEMBAHASAN}

Pada pokoknya pelaksanaan putusan (executie) adalah cara dan syarat-syarat yang dipakai oleh alat-alat kekuasaan Negara guna membantu pihak yang berkepentingan untuk menjalankan putusan hakim apabila pihak yang kalah tidak bersedia mematuhi substansi putusan dalam waktu yang ditentukan. Dalam pasal 115 Undang-undang Nomor 5 Tahun 1986 membatasi putusan pengadilan yang telah berkekuatan hukum tetap yang relevan dengan pelaksanaan, yaitu putusan yang telah diterima oleh para pihak atau tidak diajukan lagi suatu upaya hukum (banding atau kasasi). Putusan pengadilan yang belum memperoleh kekuatan hukum tetap tidak memiliki kekuatan eksekusi atau dengan kata lain putusan pengadilan yang masih mempunyai upaya hukum tidak dimintakan eksekusinya. Ada beberapa macam eksekusi antara lain sebagai berikut:

1) Eksekusi Otomatis.

Eksekusi otomatis terdapat dalam Pasal 116 ayat (1) dan (2) Undang-undang Nomor 5 Tahun 1986 dan tidak diubah oleh Undang- undang Nomor 9 Tahun 2004 dan oleh Undang-undang Nomor 51 Tahun 2009. Berdasarkan perintah Ketua Pengadilan yang mengadilinya dalam tingkat pertama salinan putusan pegadilan yang telah memperoleh kekuatan hukum tetap, dikirimkan kepada para pihak dengan surat tercatat oleh Penitera Pengadilan setempat selambat-lambatnya dalam waktu 14 (empat belas) hari setelah putusan berkekuatan hukum tetap. Dalam Undang-undang Nomor 51 Tahun 2009 ayat (1) ketentuan waktu 14 (empat belas) hari diubah menjadi 14 (empat belas) hari kerja. Putusan yang mewajibkan kepada pejabat atau badan pemerintah untuk mencabut Keputusan Tata Usaha Negara (KTUN) pada dasarnya memerlukan pelaksanaan. Namun Pasal 116 ayat (2) 
Undang-undang Nomor 5 Tahun 1986 dan Undang-undang Nomor 9 Tahun 2004 memberikan penyelesaian secara otomatis, yaitu apabila dalam waktu 4 (empat) bulan setelah putusan berkekuatan hukum tetap dikirimkan kepada pihak tergugat dan tergugat tidak melaksanakan pencabutan Keputusan Tata Usaha Negara (KTUN) yang telah dinyatakan batal tersebut, maka KTUN tersebut tidak mempunyai kekuatan hukum tetap lagi. Penyelesaian otomatis ini dipertahankan oleh Undang-undang Nomor 51 Tahun 2009. Akan tetapi ketentuan waktu 4 (empat) bulan tersebut dalam Undang-undang Nomor 51 Tahun 2009 diubah menjadi "setelah 60 (enam puluh) hari kerja diterima", tergugat tidak melaksanakan pencabutan KTUN yang bersangkutan maka obyek yang disengketakan tidak mempunyai kekuatan hukum lagi.

Menurut Pedoman Teknis Administrasi dan Teknis Peradilan Tata Usaha Negara (PERATUN), Ketua Pengadilan perlu membuat surat yang menyatakan KTUN yang dinyatakan batal atau tidak sah oleh putusan pengadilan yang telah berkekuatan hukum tetap tidak lagi mempunyai kekuatan hukum. Surat tersebut dikirimkan kepada para pihak oleh Panitera dengan surat tercatat yang pelaksanaannya dilakukan oleh juru sita. Sesuai sifat dari KTUN masih perlu mempublikasikan pernyataan tersebut agar masyarakat mengetahui bahwa KTUN yang bersangkutan sudah tidak berkekuatan hukum lagi.

2) Eksekusi Hierarkis.

Eksekusi hierarkis diatur oleh Pasal 116 ayat (3), (4) dan (5) UndangUndang Nomor 5 Tahun 1986 dan tidak lagi diterapkan setelah disahkannya Undang-undang Nomor 9 Tahun 2004. Unsur eksekusi hierarkis kembali muncul 
dalam Undang-undang Nomor 51 Tahun 2009, pada Pasal 116 ayat (6). Ketua Pengadilan diharuskan untuk mengajukan hal ketidaktaatan pejabat tergugat atau termohon eksekusi kepada Presiden sebagai pemegang kekuasaan pemerintah tertinggi untuk memerintahkan pejabat tersebut melaksanakan putusan pengadilan. Di samping itu juga mengajukannya kepada lembaga perwakilan rakyat untuk menjalankan fungsi pengawasan.

3) Eksekusi Upaya Paksa.

Pembaharuan Pasal 116 Undang-undang Nomor 5 Tahun 1986 dengan ayat (3) sampai dengan ayat (6) Undang-undang Nomor 51 Tahun 2009 mengubah mekanisme pelaksanaan Putusan Pengadilan Tata Usaha Negara dari "eksekusi hierarkis" menjadi "upaya paksa". Perubahan ini adalah sebagai koreksi terhadap lemahnya kekuasaan (power) badan peradilan yang memberikan peraturan perundang-undangan dan dinilai tidak mampu memberikan tekanan kepada pihak pejabat atau badan pemerintah untuk melaksanakan putusan. Ditentukan pada ayat (3) pasal 116 Undang-undang Nomor 9 Tahun 2004 bahwa dalam hal tergugat ditetapkan harus melaksanakan kewajibannya mencabut Keputusan Tata Usaha Negara (KTUN) dan menerbitkan KTUN yang baru atau menerbitkan KTUN dalam hal obyek gugatan fiktif negatif dan kemudian setelah 3 (tiga) bulan sejak putusan disampaikan kepada pihak tergugat (menurut Undang-undang Nomor 51 Tahun 2009, 90 (sembilan puluh) hari kerja sejak diterima) dan ternyata kewajiban tersebut tidak dilaksanakan, penggugat mengajukan permohonan kepada Ketua Pengadilan yang mengadili pada tingkat pertama agar memerintahkan tergugat melaksanakan 
putusan pengadilan tersebut. Perubahan Undang-undang Nomor 51 Tahun 2009 pada dasarnya tidak mengubah cara upaya paksa ini.

Setelah Ketua Pengadilan memerintahkan untuk melaksanakan putusan (Pasal 116 ayat (4) dan (5) Undang-undang Nomor 9 Tahun 2004 dan Undangundang Nomor 51 Tahun 2009) ternyata tergugat tidak bersedia melaksanakannya, maka terhadap pejabat yang bersangkutan dikenakan upaya paksa berupa "pembayaran sejumlah uang paksa" dan/ atau "sanksi administratif" dan pejabat yang tidak melaksanakan putusan pengadilan sebagaimana dimaksud "diumumkan pada media massa cetak setempat oleh Panitera sejak tidak terpenuhinya ketentuan tersebut".

Dalam pelaksanaan putusan Peradilan Tata Usaha Negara tidak dimungkinkan adanya upaya paksa dengan menggunakan aparat keamanan, seperti halnya dalam pelaksanaan putusan Peradilan Pidana dan Peradilan Perdata. Tetapi istimewanya dalam pelaksanaan putusan Peradilan Tata Usaha Negara dimungkinkan campur tangan Presiden sebagai Kepala Pemerintahan yang bertanggung jawab dalam pembinaan aparatur pemerintahan juga bertanggung jawab agar setiap aparatur pemerintahan dapat mentaati semua peraturan perundang-undangan yang berlaku termasuk mentaati Putusan Pengadilan sesuai dengan prinsip Negara hukum yang kita anut. Campur tangan presiden diperlukan karena yang bersangkutan adalah orang atau badan hukum Perdata dengan Badan atau Pejabat Tata Usaha Negara dan yang dapat digugat di Pengadilan di lingkungan Peradilan Tata Usaha Negara adalah Badan atau Pejabat Tata Usaha Negara yang dapat mengeluarkan suatu putusan Tata Usaha Negara.

Berkaitan dengan mekanisme eksekusi putusan Pengadilan Tata Usaha Negara, terbagi berdasarkan phase sebelum berlakunya Undang-undang Nomor 9 Tahun 2004 yaitu ketentuan 
yang diatur dalam Undang-undang Nomor 5 Tahun 1986, phase setelah berlakunya Undangundang Nomor 9 Tahun 2004 dan Undang- undang Nomor 51 Tahun 2009 tentang Perubahan Kedua Undang-undang Nomor 5 Tahun 1986 tentang Peradilan Tata Usaha Negara.

1) Eksekusi Berdasarkan Ketentuan Undang-undang Nomor 5 Tahun 1986

Ketentuan eksekusi putusan Pengadilan Tata Usaha Negara dalam Undang-undang Nomor 5 Tahun 1986 diatur pada Bagian Kelima mengenai Pelaksanaan Putusan Pengadilan dalam Pasal 115 sampai dengan Pasal 119. Adapun mekanisme eksekusi putusan Pengadilan Tata Usaha Negara menurut ketentuan diatur dalam Pasal 116 Undang-undang Nomor 5 Tahun 1986, isi selengkapnya adalah:

a. Salinan putusan pengadilan yang telah memperoleh kekuatan hukum tetap, dikirimkan kepada para pihak dengan surat tercatat oleh Panitera Pengadilan setempat atas perintah Ketua Pengadilan yang mengadilinya dalam tingkat pertama selambat-lambatnya dalam waktu 14 (empat belas) hari.

b. Dalam hal 4 (empat) bulan setelah putusan Pengadilan yang telah memperoleh kekuatan hukum tetap sebagaimana dimaksud dalam ayat (1) dikirimkan tergugat tidak melaksanakan kewajibannya sebagaimana dimaksud dalam Pasal 97 ayat (9) huruf a, maka Keputusan Tata Usaha Negara yang disengketakan itu tidak mempunyai kekuatan hukum lagi.

c. Dalam hal tergugat ditetapkan harus melaksanakan kewajibannya sebagaimana dimaksud dalam Pasal 97 ayat (9) huruf b dan c, dan kemudian setelah 3 (tiga) bulan ternyata kewajiban tersebut tidak dilaksanakannya, maka penggugat mengajukan permohonan kepada Ketua Pengadilan sebagaimana dimaksud 
dalam ayat (1), agar Pengadilan memerintahkan tergugat melaksanakan putusan Pengadilan tersebut.

d. Jika tergugat masih tetap tidak mau melaksanakannya, Ketua Pengadilan mengajukan Hal ini kepada instansi atasannya menurut jenjang jabatan.

e. Instansi atasan sebagaimana dimaksud dalam ayat (4), dalam waktu 2 (dua) bulan setelah menerima pemberitahuan dari Ketua Pengadilan harus sudah memerintahkan pejabat sebagaimana dimaksud dalam ayat (3) melaksanakan putusan Pengadilan tersebut.

f. Dalam hal instansi atasan sebagaimana dimaksud dalam ayat (4), tidak mengindahkan ketentuan sebagaimana dimaksud dalam ayat (5), maka Ketua Pengadilan mengajukan hal ini kepada Presiden sebagaimana pemegang kekuasaan pemerintah tertinggi untuk memerintahkan pejabat tersebut melaksanakan putusan Pengadilan tersebut.

Pelaksanaan putusan Pengadilan Tata Usaha Negara dikenal ada 2 (dua) jenis eksekusi putusan, yaitu: eksekusi putusan yang berisi kewajiban sebagaimana yang dimaksud dalam ketentuan Pasal 97 ayat (9) Sub a, yakni:

a) Mekanisme Eksekusi melalui Pencabutan Keputusan Tata Usaha Negara yang Bersangkutan (Disengketakan).

Putusan Pengadilan Tata Usaha Negara yang berisi kewajiban Pencabutan Keputusan Tata Usaha Negara kepada Tergugat, maka diterapkanlah eksekusi putusan menurut ketentuan Pasal 116 ayat (2) Undang-undang Nomor 5 Tahun 1986 yaitu 4 (empat) bulan setelah putusan pengadilan yang telah memperoleh kekuatan hukum tetap sebagaimana dimaksud dalam Pasal 116 ayat 
(1) dikirimkan, tergugat tidak melaksanakan kewajibannya, maka Keputusan Tata Usaha Negara yang disengketakan tersebut tidak mempunyai kekuatan hukum lagi. Mekanisme eksekusi ini bisa dikatakan sebagai eksekusi otomatis . Dikatakan otomatis oleh karena apabila dikaitkan dengan prinsip keabsahan (rechtmatigheid) tindakan Pemerintah, dalam hal ini Keputusan Tata Usaha Negara di mana prinsip tersebut terkait dengan batas kepatuhan kepada hukum, maka keputusan hukum yang tidak sah, dengan sendirinya tidak mempunyai kekuatan mengikat dan dengan demikian tidak ada kewajiban untuk memenuhi keputusan yang tidak sah dan dengan demikian pula tidak perlu adanya eksekusi putusan, kecuali yang menyangkut kewajiban tertentu yang harus dilaksanakan sehubungan dengan dinyatakan tidak sahnya Keputusan Tata Usaha Negara

b) Mekanisme Eksekusi Melalui Instansi Atasan (dikenal dengan adanya Pencabutan Keputusan Tata Usaha Negara yang bersangkutan dan menerbitkan Keputusan Tata Usaha Negara yang baru

Mekanisme eksekusi putusan Pengadilan Tata Usaha Negara melalui Instansi Atasan diterapkan apabila adanya putusan yang berisi kewajiban sebagaimana yang ditentukan dalam Pasal 97 ayat (9) sub b dan c, yakni (b) pencabutan Keputusan Tata Usaha Negara yang bersangkutan dan menerbitkan Keputusan Tata Usaha Negara yang baru;

c) Mekanisme Eksekusi Melalui Penerbitan Keputusan Tata Usaha Negara dalam hal gugatan 
Didasarkan pada Pasal 3, Pasal 97 ayat (10), yakni Kewajiban sebagaimana dimaksud dalam ayat (9) dapat disertai pembebanan ganti rugi, dan Pasal 97 ayat (11), dalam hal putusan Pengadilan sebagaimana dimaksud dalam ayat (8) menyangkut kepegawaian, maka disamping kewajiban sebagaimana dimaksud dalam ayat (9) dan ayat (10), dapat disertai pemberian rehabilitasi, maka diterapkanlah ketentuan eksekusi putusan menurut ketentuan Pasal 116 ayat (3) sampai ayat (6) Undang-undang Nomor 5 Tahun 1986, yaitu dalam hal Badan atau Pejabat Tata Usaha Negara ditetapkan harus melaksanakan kewajiban sebagaimana tersebut dalam amar putusan untuk menerbitkan Keputusan Tata Usaha Negara, tetapi ternyata setelah 3 (tiga) bulan lewat, dan kewajiban itu tidak dipenuhi, maka penggugat mengajukan permohonan kepada Ketua Pengadilan yang berwenang agar pengadilan memerintahkan tergugat untuk melaksanakan putusan pengadilan tersebut.

Jika tergugat masih tidak mau melaksanakannya, Ketua Pengadilan mengajukan hal itu kepada instansi atasannya menurut jenjang jabatan. Instansi atasan ini dalam waktu 2 (dua) bulan setelah menerima pemberitahuan dari Ketua Pengadilan harus sudah memerintahkan Badan atau Pejabat Tata Usaha Negara yang berkewajiban menerbitkan Keputusan Tata Usaha Negara untuk melaksanakan Putusan Pengadilan. Apabila ternyata instansi atasan tersebut tidak mengindahkan pemberitahuannya, maka Ketua Pengadilan mengajukan hal ini kepada Presiden sebagai pemegang kekuasaan pemerintah tertinggi untuk memerintahkan Badan atau Pejabat Tata Usaha Negara tersebut 
melaksanakan Putusan Pengadilan yang bersangkutan. Cara eksekusi seperti ini merupakan mekanisme "eksekusi hierarkis".

2) Eksekusi Berdasarkan Ketentuan Undang-undang Nomor 9 Tahun 2004

Pengaturan eksekusi putusan Pengadilan Tata Usaha Negara dalam Undang-undang Nomor 9 Tahun 2004 diatur pada Pasal 116, khususnya yang bertalian dengan amar putusan yang berisi kewajiban pencabutan Keputusan Tata Usaha Negara yang bersangkutan dan penerbitan Keputusan Tata Usaha yang baru, dan amar putusan yang berisi kewajiban penerbitan Keputusan Tata Usaha Negara dalam hal gugatan didasarkan Pasal 3, sebagaimana diatur dalam Pasal 97 ayat (9) sub b dan c Undang-undang Nomor 5 Tahun 1986. Pasal 116 Undang-undang Nomor 9 Tahun 2004 selengkapnya berbunyi sebagai berikut:

a) Salinan putusan Pengadilan yang telah memperoleh kekuatan hukum tetap, dikirimkan kepada para pihak dengan surat tercatat oleh Panitera Pengadilan setempat atas perintah Ketua Pengadilan yang mengadilinya dalam tingkat pertama selambat-lambatnya dalam waktu 14 (empat belas) hari.

b) Dalam hal 4 (empat) bulan setelah putusan Pengadilan yang telah memperoleh kekuatan hukum tetap sebagaimana dimaksud pada ayat (1) dikirimkan, tergugat tidak melaksanakan kewajibannya sebagaimana dimaksud dalam Pasal 97 ayat (9) huruf a, Keputusan Tata Usaha Negara yang disengketakan itu tidak mempunyai kekuatan hukum lagi. 
c) Dalam hal tergugat ditetapkan harus melaksanakan kewajibannya sebagaimana dimaksud dalam Pasal 97 ayat (9) huruf b dan huruf c, dan kemudian setelah 3 (tiga) bulan ternyata kewajiban tersebut tidak dilaksanakannya, penggugat mengajukan permohonan kepada Ketua Pengadilan sebagaimana dimaksud pada ayat (1) agar Pengadilan memerintahkan tergugat melaksanakan putusan Pengadilan tersebut.

d) Dalam hal tergugat tidak bersedia melaksanakan putusan Pengadilan yang telah memperoleh kekuatan hukum tetap, terhadap pejabat yang bersangkutan dikenakan upaya paksa berupa pembayaran sejumlah uang paksa dan/ atau sanksi administratif.

e) Pejabat yang tidak melaksanakan putusan pengadilan sebagaimana dimaksud pada ayat (4) diumumkan pada media massa cetak setempat oleh Panitera sejak tidak terpenuhinya ketentuan sebagaimana dimaksud pada ayat (3).

Dalam ketentuan Pasal 116 ayat (4) disebutkan sanksi pembayaran uang paksa dan sanksi administratif. Sanksi merupakan penerapan alat kekuasaan (machtsmiddelen) sebagai reaksi atas pelanggaran norma hukum administrasi. Ciri khas penegakan hukum adalah paksaan (dwang). Sedangkan penerapan sanksi merupakan langkah refresif untuk melaksanakan kepatuhan. Penegakan hukum administrasi seringkali diartikan sebagai penerapan sanksi 
administrasi. Jenis-jenis sanksi administrasi tersebut antara lain sebagau berikut:

a ) Paksaan nyata (bestuursdwang)

Paksaan nyata dirumuskan sebagai tindakan nyata untuk memindahkan, mengosongkan, menghalang-halangi, memperbaiki pada keadaan semula apa yang sedang dilakukan atau telah dilakukan yang bertentangan dengan kewajiban-kewajiban yang ditentukan oleh peraturan perundang-undangan (Pasal 6.2.1 AWB: Algemene Wet Bestuursrecht).

b ) Uang paksa (dwangsom)

Uang paksa dikenakan sebagai alternatif untuk paksaan nyata.

c) Denda administrasi.

Denda administrasi lebih bersifat "condemnatoir" daripada sifat "reparatoir". Untuk mengenakan denda administrasi dibutuhkan ketentuan peraturan perundang-undangan tentang wewenang untuk itu. Juga ketentuan tentang maksimum denda yang dapat diterapkan.

d) Pencabutan Keputusan Tata Usaha Negara yang menguntungkan Pencabutan sebagai sanksi administrasi merupakan wewenang yang melekat pada wewenang menetapkan Keputusan Tata Usaha Negara. Sifat pencabutan sebagai sanksi, bisa reparatoir, bisa juga condemnatoir.

e) Uang Jaminan 
Uang jaminan berkenaan dengan suatu keputusan yang menguntungkan, misalnya izin. Uang jaminan dapat merupakan syarat bagi suatu izin dan uang jaminan itu dinyatakan hilang apabila syarat yang diwajibkan dalam pemberian izin ternyata tidak dipenuhi. Dikaitkan dengan suatu keputusan yang menguntungkan (pemberian izin misalnya). Uang jaminan bersifat preventif sedangkan dikaitkan dengan kompensasi kerugian, sifatnya "reparatoir" dan dikaitkan dengan paksaan sifatnya "condemnatoir".

3) Eksekusi Berdasarkan Ketentuan Undang-undang Nomor 51 Tahun 2009

Pengaturan eksekusi putusan Pengadilan Tata Usaha Negara dalam Undang-undang Nomor 51 Tahun 2009 yang telah disahkan oleh Dewan Perwakilan Rakyat (DPR) pada akhir September 2009,. Pasal 116 Undangundang Nomor 51 Tahun 2009 tentang Perubahan Kedua Undang-undang Nomor 5 Tahun 1986 tentang Peradilan Tata Usaha Negara selengkapnya berbunyi:

(1) Salinan putusan pengadilan yang telah memperoleh kekuatan hukum tetap, dikirimkan kepada para pihak dengan surat tercatat oleh panitera pengadilan setempat atas perintah ketua pengadilan yang mengadilinya dalam tingkat pertama selambat-lambatnya dalam waktu 14 (empat belas) hari kerja.

(2) Apabila setelah 60 (enam puluh) hari kerja putusan pengadilan yang telah memperoleh kekuatan hukum tetap sebagaimana dimaksud pada ayat (1) diterima tergugat tidak melaksanakan kewajibannya sebagaimana dimaksud 
dalam Pasal 97 ayat (9) huruf a, keputusan tata usaha negara yang disengketakan itu tidak mempunyai kekuatan hukum lagi.

(3) Dalam hal tergugat ditetapkan harus melaksanakan kewajiban sebagaimana dimaksud dalam Pasal 97 ayat (9) huruf b dan huruf c, dan kemudian setelah 90 (Sembilan puluh) hari kerja ternyata kewajiban tersebut tidak dilaksanakan, maka penggugat mengajukan permohonan kepada ketua pengadilan sebagaimana dimaksud pada ayat (1), agar pengadilan memerintahkan tergugat melaksanakan putusan pengadilan tersebut.

(4) Dalam hal tergugat tidak bersedia melaksanakan putusan pengadilan yang telah memperoleh kekuatan hukum tetap, terhadap pejabat yang bersangkutan dikenakan upaya paksa berupa pembayaran sejumlah uang paksa dan/ atau sanksi administratif.

(5) Pejabat yang tidak melaksanakan putusan pengadilan sebagaimana dimaksud pada ayat (4) diumumkan pada media massa cetak setempat oleh panitera sejak tidak terpenuhinya ketentuan sebagaimana dimaksud pada ayat (3).

(6) Di samping diumumkan pada media massa cetak setempat sebagaimana dimaksud pada ayat (5), ketua pengadilan harus mengajukan hal ini kepada Presiden sebagaimana pemegang kekuasaan pemerintahan tertinggi untuk memerintahkan pejabat tersebut melaksanakan putusan pengadilan, dan kepada lembaga perwakilan rakyat untuk menjalankan fungsi pengawasan.

(7) Ketentuan mengenai besaran uang paksa, jenis sanksi administratif, dan tata cara pelaksanaan pembayaran uang paksa dan/ atau sanksi administratif diatur dengan peraturan perundang-undangan. 


\section{PENUTUP}

Di Indonesia Pelaksanaan putusan Pengadilan Tata Usaha Negara berupa eksekusi di atur pada pasal 115 dan 116 UU No. 5 Tahun 1986, yang sudah mengalami perubahan dengan dikeluarkannya UU No. 9 tahun 2004 dan UU No. 51 Tahun 2009. Macam-macam eksekusi antara lain: eksekusi otomatis, eksekusi hierarkis, dan eksekusi upaya paksa. Ada tiga fase berkaitan dengan mekanisme eksekusi putusan Pengadilan Tata Usaha. Pertama, fase sebelum berlakunya Undang-undang Nomor 9 Tahun 2004 yaitu ketentuan yang diatur dalam Undangundang Nomor 5 Tahun 1986, kedua fase setelah berlakunya Undang-undang Nomor 9 Tahun 2004 dan ketiga, fase Undang-undang Nomor 51 Tahun 2009 tentang Perubahan Kedua Undang-undang Nomor 5 Tahun 1986 tentang Peradilan Tata Usaha Negara. Penerapan sanksi administrasi dalam pelaksanaan putusan Pengadilan Tata Usaha Negara terdiri dari paksaan nyata, uang paksa, denda administrasi, pencabutan keputusan tata usaha negara yang menguntungkan, serta uang jaminan.

Campur tangan Presiden dalam eksekusi putusan Pengadilan Tata Usaha Negara memang diperlukan mengingat eksekusi pada Pengadilan Tata Usaha Negara tidaklah semudah dalam eksekusi putusan badan Peradilan Umum (perdata maupun pidana). Presiden sebagai kepala pemerintahan bertanggung jawab terhadap pembinaan Pegawai Negeri atau Aparatur Pemerintahan, tentunya juga bertanggung jawab agar setiap aparatur pemerintahan dapat menaati semua peraturan perundang-undangan yang berlaku termasuk mentaati putusan pengadilan sesuai dengan prinsip negara hukum. Diharapkan dengan adanya pelaksanaan putusan Pengadilan Tata Usaha Negara sebagai wujud adanya lembaga kontrol atau pengawas agar tindakan-tindakan hukum dari pemerintah (bestuur) tetap berada dalam rel hukum, disamping sebagai pelindung hak warga masyarakat terhadap penyalahgunaan wewenang atau kesewenang-wenangan aparatur pemerintah. 


\section{DAFTAR PUSTAKA}

Darmini Roza dan Laurensius Arliman S Peran Pemerintah Daerah Di Dalam Melindungi Hak Anak Di Indonesia, Masalah-Masalah Hukum, Volume 47, Nomor 1, 2018.

Laurensius Arliman S, Komnas HAM dan Perlindungan Anak Pelaku Tindak Pidana, Deepublish, Yogyakarta, 2015.

Laurensius Arliman S, Penguatan Perlindungan Anak Dari Tindakan Human Trafficking Di Daerah Perbatasan Indonesia, Jurnal Selat, Volume 4, Nomor 1, 2016.

Laurensius Arliman S, Problematika Dan Solusi Pemenuhan Perlindungan Hak Anak Sebagai Tersangka Tindak Pidana Di Satlantas Polresta Pariaman, Justicia Islamica, Volume 13, Nomor 2, 2016.

Laurensius Arliman S, Pelaksanaan Perlindungan Anak Yang Tereksploitasi Secara Ekonomi Oleh Pemerintah Kota Padang, Veritas et Justitia, Volume 2, Nomor 1, 2016.

Laurensius Arliman S, Kedudukan Ketetapan MPR Dalam Hierarki Peraturan PerundangUndangan Di Indonesia, Lex Jurnalica, Volume 13, Nomor 3, 2016.

Laurensius Arliman S, Komnas Perempuan Sebagai State Auxialiary Bodies Dalam Penegakan Ham Perempuan Indonesia, Justicia Islamica, Volume 14, Nomor 2, 2017.

Laurensius Arliman S, Peranan Pers Untuk Mewujudkan Perlindungan Anak Berkelanjutan Di Indonesia, Jurnal Ilmu Hukum Tambun Bungai, Volume 2, Nomor 2, 2017.

Laurensius Arliman S, Mewujudkan Penegakan Hukum Yang Baik Untuk Mewujudkan Indonesia Sebagai Negara Hukum, Jurnal Hukum Doctrinal, Volume 2, Nomor 2, 2017.

Laurensius Arliman S, Participation Non-Governmental Organization In Protecting Child Rights In The Area Of Social Conflict, The 1st Ushuluddin and Islamic Thought International Conference (Usicon), Volume 1, 2017.

Laurensius Arliman S, Partisipasi Masyarakat Dalam Pembentukan Perundang- Undangan Untuk Mewujudkan Negara Kesejahteraan Indonesia, Jurnal Politik Pemerintahan Dharma Praja, Volume 10, Nomor 1, 2017, https://doi.org/10.33701/jppdp.v10i1.379.

Laurensius Arliman S, Peran Komisi Perlindungan Anak Indonesia Untuk Mewujudkan Perlindungan Anak, Jurnal Respublica Volume 17, Nomor 2, 2018.

Laurensius Arliman S, Menjerat Pelaku Penyuruh Pengrusakan Barang Milik Orang Lain Dengan Mempertimbangkan Asas Fungsi Sosial, Jurnal Gagasan Hukum, Volume 1, Nomor 1, 2019. 
Laurensius Arliman S, Ilmu Perundang-Undangan Yang Baik Untuk Negara Indonesia, Deepublish, Yogyakarta, 2019.

Laurensius Arliman S, Isdal Veri, Gustiwarni, Elfitrayenti, Ade Sakurawati, Yasri, Pengaruh Karakteristik Individu, Perlindungan Hak Perempuan Terhadap Kualitas Pelayanan Komnas Perempuan Dengan Kompetensi Sumber Daya Manusia Sebagai Variabel Mediasi, Jurnal Menara Ekonomi: Penelitian dan Kajian Ilmiah Bidang Ekonomi, Volume 6, Nomor 2, 2020.

Laurensius Arliman S, Pendidikan Kewarganegaraan, Deepublish, Yogyakarta, 2020.

Laurensius Arliman S, Makna Keuangan Negara Dalam Pasal Pasal 23 E Undang-Undang Dasar 1945, Jurnal Lex Librum, Volume 6, Nomor 2 Juni 2020, http://dx.doi.org/10.46839/1ljih.v6i2.151.

Laurensius Arliman S, Kedudukan Lembaga Negara Independen Di Indonesia Untuk Mencapai Tujuan Negara Hukum, Kertha Semaya Journal Ilmu Hukum, Volume 8, Nomor 7, 2020.

Laurensius Arliman S, Pelaksanaan Assesment Oleh Polres Kepulauan Mentawai Sebagai Bentuk Pelaksanaan Rehabilitasi Bagi Pecandu Dan Korban Penyalahgunaan Narkotika, Jurnal Muhakkamah, Volume 5, Nomor 1, 2020.

Laurensius Arliman S, Aswandi Aswandi, Firgi Nurdiansyah, Laxmy Defilah, Nova Sari Yudistia, Ni Putu Eka, Viona Putri, Zakia Zakia, Ernita Arief, Prinsip, Mekanisme Dan Bentuk Pelayanan Informasi Kepada Publik Oleh Direktorat Jenderal Pajak, Volume 17, No Nomor, 2020.

Larensius Arliman S, Koordinasi PT. Pegadaian (Persero) Dengan Direktorat Reserse Narkoba Polda Sumbar Dalam Penimbangan Barang Bukti Penyalahgunaan Narkotika, UIR Law Review, Volume 4, Nomor 2, 2020, https://doi.org/10.25299/uirlrev.2020.vol4(1).3779.

Laurensius Arliman S, Tantangan Pendidikan Kewarganegaraan Pada Revolusi 4.0, Ensiklopedia Sosial Review, Volume 2, Nomor 3, 2020.

Muhammad Afif dan Laurensius Arliman S, Protection Of Children's Rights Of The Islamic And Constitutional Law Perspective Of The Republic Of Indonesia, Proceeding: Internasional Conference On Humanity, Law And Sharia (Ichlash), Volume 1, Nomor 2, 2020.

Otong Rosadi danLaurensius Arliman S, Urgensi Pengaturan Badan Pembinaan Idelogi Pancasila Berdasarkan Undang-Undang Sebagai State Auxiliary Bodies yang Merawat Pancasila dalam Perspektif Hak Asasi Manusia, Prosiding Konferensi Nasional Hak Asasi Manusia, Kebudayaan dan Tujuan Pembangunan Berkelanjutan Indonesia pada Masa Pandemi Covid-19: Tantangan untuk Keilmuan Hukum dan Sosial Volume 1, Universitas Pancasila, Jakarta, 2020. 